\title{
SCREENING INDIGENOUS AUSTRALIA: SPACE, PLACE AND MEDIA IN FRANCES CALVERT'S TALKING BROKEN
}

\author{
Peter Kilroy* \\ King's College London \\ London, UK
}

\begin{abstract}
Drawing on the fields of postcolonial studies and media theory, this article analyzes Frances Calvert's 1990 documentary, Talking Broken, which, inter alia, looks at the role of space, place and media amongst Australia's "other" Indigenous community, Torres Strait Islanders. The article explores the historical and geographical complexity of the space-place-media relation, particularly in terms of the centre-periphery relations between the Torres Strait and the Australian mainland, and considers the extent to which Calvert, after the Australian bicentenary of 1988, is able to absorb and playfully challenge such formulations. More broadly, it considers the extent to which contemporary Indigenous media might go further and enact a shift from absorbing and challenging such formulations to taking control of media institutions themselves.
\end{abstract}

Keywords: Postcolonial Studies; Indigenous Media; Torres Strait Islands; Documentary Film

\section{Prologue: Postcolonial Studies and Media Theory}

Nearly two decades ago, the art historian María Fernández (1999) wrote an important polemical article about the relative lack of mutual engagement between postcolonial studies and media theory. Polemical generalizations aside (neither are unitary fields, nor do they sit still ${ }^{1}$ ), one might be forgiven for hoping for greater mutual engagement today. However, despite growing moves towards a contemporary rapprochement ${ }^{2}$ (and Indigenous media studies seems to me the most fruitful meeting ground at present, e.g. Wilson and Stewart; Hokowhitu and Devadas), it is still possible to leaf through canonical readers in both fields (e.g. Ashcroft, Griffiths and Tiffin; Thornham, Bassett and Marris) and find a relatively limited set of mutual references. This is puzzling, not least because postcolonial studies' thematic interest in questions of space, place, property and land, and how they are mediated by language, seems particularly apt to be addressed from the perspective of recording and communications media and vice versa.

Such a move would not only involve treating media as a series of semiotic surfaces to be analyzed (e.g. applying a "literary" analysis to a "reading" of postcolonial photographs or films, etc.), but also "placing" such media, i.e. locating them in a set of social, economic and cultural contexts (e.g. the role of radio, television or film in the construction of Indigenous place, or the incorporation of colonial media within Indigenous land rights claims, etc.).

I offer this observation less as a polemic or detailed argument, however-one could easily cite counter examples (footnote 2)-and more as an invitation to explore some of the possibilities of mutual dialogue through a specific case study: the spatial and filmic representation (or cultural and technological mediation) of Australia's "other" Indigenous community, Torres Strait Islanders and their descendants.

\footnotetext{
${ }^{*}$ Peter Kilroy is a British Academy Postdoctoral Fellow at the Menzies Centre for Australian Studies and the Department of Film Studies at King's College London, UK. His main research interests are in colonial, postcolonial and Indigenous media, with a particular emphasis on photography, phonography, and film. His email address is peter.kilroy@kcl.ac.uk
} 


\section{Space, Place and the Torres Strait Islands}

The Torres Strait Island region-home to Australia's Melanesian Indigenous community-comprises a series of five island groups situated between Papua New Guinea to the north and the Australian mainland to the south, between the Coral and Arafura Seas, and, beyond that, the Pacific and Indian Oceans to the East and the West (Beckett 26-32), and that anomalous and heavily mediated spatial position is an important part of what I want to address in this article. For more than 200 years, the Strait has, in many idiosyncratic ways, defined and challenged Australia, or represented its spatial limitpoint as well as its dangerously porous border. In other words, it is the periphery that redefines the centre, nationally and internationally.

When Captain Cook and crew navigated the east coast of the continent in 1770, from south to north, he only took possession in the name of the King when he discovered the dotted line that divided the landmass from its "other", its outside, and that line was marked by the Torres Strait Islands (Cook, 22 August 1770). They represented the geographical beginning and end of what would become "Australia". These islands, though, were not claimed by Cook; they were "outside" Australia, on the other side of the dotted line, despite forming part of Joseph Bank's "Labyrinth of Shoals", the Great Barrier Reef (Banks, 20 July 1770).

However, by the mid-nineteenth century the islands had become a site of considerable strategic significance, not least in being at the centre of a booming global trade in pearl shell and bêche-demer (sea cucumber) (Beckett ch. 2). This entangled them, as well as making them global agents, in an international trading network spanning Europe and Asia, Papua New Guinea and Australia. Given this strategic significance, the colony of Queensland came to annex the islands between 1872 and 1879 bringing them officially "inside" the Commonwealth of Australia upon federation in 1901 (Beckett ch. 2). The price of this inclusion, however, was that the islands would become part of Australia's dangerously porous border during the Second World War, subject to Japanese attack, and after the war, such a border threatened an opening to the Cold War threat from the north (Beckett ch. 3). In 1992, the successful outcome of one of Australia's most famous land rights cases, Mabo v. Queensland No. 2, which began on the eastern Torres Strait Island of Mer, threatened to set a precedent for the continent as a whole (Sharp 1999; Graham 1990, 1997), and today, when Australia has outsourced much of its "processing" of asylum seekers to Manus Island and Nauru to the north, the Torres Strait is once again often posed as a threatening opening to the nationstate-to the body politic-both in terms of the flow of people and the flow of wildlife and diseases, etc.

All of which is to say that the Torres Strait Islands are marked by a hybrid spatial inbetweenness that has to be policed, mediated and anxiously repeated, lest a border breach leads the periphery to redefine or challenge the centre. This occurs on both an eastwest axis between Asia and Europe and a north-south axis between Papua New Guinea and Australia. Like a hyphen that both joins and separates, the islands are both a bridge and a barrier between such compass points and, as a consequence, have long been "screened" as a medical, political or economic threat, or "screened off" as a protected, invisible or exoticized "other".

However, in part because of an extensive, and heavily mediatized, anthropological expedition to the islands in 1898, which included photographic, phonographic and cinematic representations (Herle and Rouse), Torres Strait Islanders have also long been "screened" as cinematic subjects or, perhaps, objects. Indeed, there is a one hundred and twenty year history of filmic representations of Torres Strait Islanders (see the film and television section), much of which has, up until relatively recently, codified a set of conventions that attempt to conceal, mitigate or otherwise assimilate the complexity of this hybrid spatial inbetweenness by representing the islands as either isolated, set apart and disconnected from the complexities of colonial modernity or, often more likely, as passively subject to them.

\section{The Australian Bicentenary (1988)}

However, such conventions began to be critically scrutinized after the Australian bicentenary of 1988, 
which commemorated two hundred years since the first fleet of convicts and "settlers" sailed from Portsmouth, England and landed in Botany Bay, just south of their final chosen destination of Port Jackson or modern-day Sydney Harbour. As part of a wider and building set of concerns with Indigenous cultural politics and national refashioning (Bennett, Buckridge, Carter and Mercer; Turner), this period was marked by three important trends in Torres Strait film: one was a numerical proliferation of documentary films, where previously there had only been a small number; two was an explicit thematic concern with politics, land rights and cultural ownership; and three was a re-use or "remediation" of prior films and other archival media in order to address those concerns (such as photographs, maps and sound recordings, etc.; and I will come back to the question of remediation later). It should be noted that 1988 was also the year in which the Torres Strait launched a campaign to secede from the state of Queensland marking this as a time of ferment and redefinition across the Torres Strait and Australia more generally (Sharp 1993, chs 7-8).

\section{Frances Calvert: Talking Broken}

Oneofthekeyprotagonistsofthispost-88 movement was the Australian-born and Berlin-based filmmaker Frances Calvert, and I want to focus here on her debut film, Talking Broken, which was released in 1990 just after the bicentenary and the secession attempt. ${ }^{3}$ This 76 minute film, funded jointly by the UK and Germany, ${ }^{4}$ is a "post-colonial" portrait of the local/global complexity of Islander life circa late 1980s Australia, with thematic sections covering tourism, politics, economics, sex, religion and media. The "Broken" of the title is a form of Torres Strait Creole (sometimes called Yumplatok), which is spoken alongside English and several other Indigenous languages on the islands, including Kala Lagaw Ya and Meriam Mir (The State Library of Queensland), but in my reading it is also a metaphor for forms of productive, strategic and globally mediatized hybridity, an impurity without nostalgia for the pure. In that sense, the film's subtitle, "voices from the Torres Strait", is less an attempt to reclaim an essentialized Indigeneity under threat from a global and mediatized modernity and more an exploration of the complexity and fractured multiplicity of contemporary Indigenous lives. "The theme", Calvert suggests in a 1997 interview, "is social change and the question was always"

how do Torres Strait Islanders see their development and their future in a First World country in view of the fact that they are Melanesians, and see themselves as separate from Australian Aborigines and Papuans? I interviewed countless people and became friends with many. Talking Broken is about this encounter and the way they constructed their identity. (Calvert 1999, 12)

I want to look at this film for two inter-related reasons. The first is that it explicitly thematizes the relationship between space, place and media in a postcolonial context, particularly in relation to film, television, radio and telephony, and the second is that it is set in a wider media context that includes national distribution (in educational institutions and museums, etc.) and international distribution (for TV, film festivals and DVD sales, etc.). I will attempt to address some of these themes by focusing in particular on the film's characteristically idiosyncratic leitmotif: an aerial shot of a helicopter bearing a telephone-booth on a wire (figure 1).

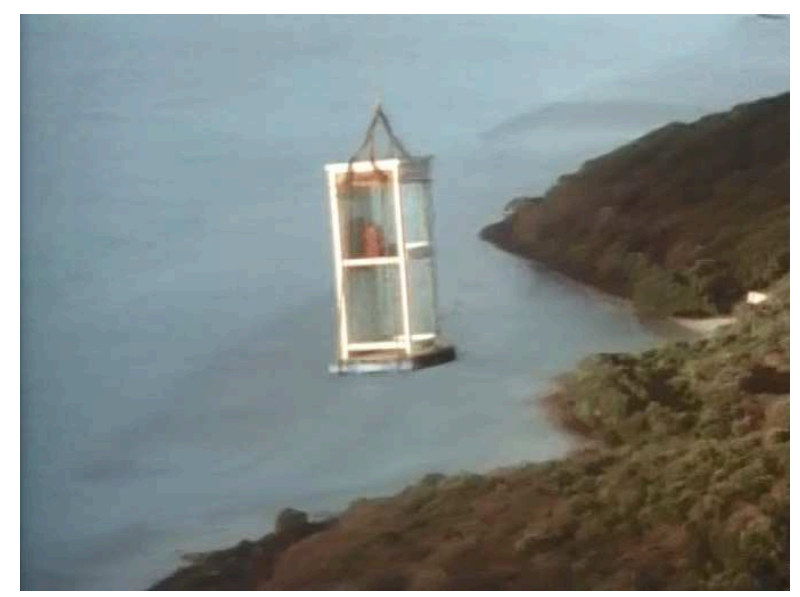

Figure 1: Screenshot from Talking Broken - The "talking broken" motif, 1 (c) 1990 Frances Calvert

This motif-the "talking broken" motif-functions as a structural device, bookending the film and separating 
out and introducing its thematic sections. It was also used in much of the promotional material for the film (e.g. in posters and on websites, etc.). It should be stressed that this was an abstract or "staged" shot for the purposes of the film, but drew upon a genuine state plan to bring public telephony to the more remote islands. However, its use as a leitmotif in the film requires some unpacking here.

\section{The "Talking Broken" Motif}

As Robert Dixon explores in his 2001 book, Prosthetic Gods, one of the archetypal demonstrations of the imperial power/visual representation nexus is that of the aerial shot (Dixon ch. 2). This figure does a number of things at once, most notably deploying a panoptic, cartographic or God's-eye view that renders itself, and its technological mediation, invisible in the process of its deployment. In some senses, the more invisible or taken-for-granted its mediation is, the more powerful are its effects. This is a good example of Bolter and Grusin's (1999) concept of "remediation" (i.e. where one medium absorbs the conventions of another. For example, early photography using the genres of painting or early film using the conventions of theatre, etc.). In this case, we see film adopting or absorbing the pre-filmic visual conventions of cartography. Paul Virilio (2009) has made a similar point in terms of the relationship between aerial-vision and war, and the First World War is particularly interesting in that context.

In the case of the Australian-controlled territory of Papua and the Torres Strait, such a convention began with Frank Hurley's documentary and feature films of the 1920s, some of the first of their kind to use aerial footage in this context (Australian Screen), but this convention has arguably become the visual cliché of the opening or establishing shots in Torres Strait film, positioning the islands spatially in relation to themselves and/or to the locality, the net rhetorical or semiotic effect of which is often to suggest disconnection and geographical or cultural distance conquered by technocratic power. ${ }^{5}$ This is the ethnographic or documentary film equivalent of the power-laden and scene-setting "arrival" in classic ethnographic texts (Pratt).

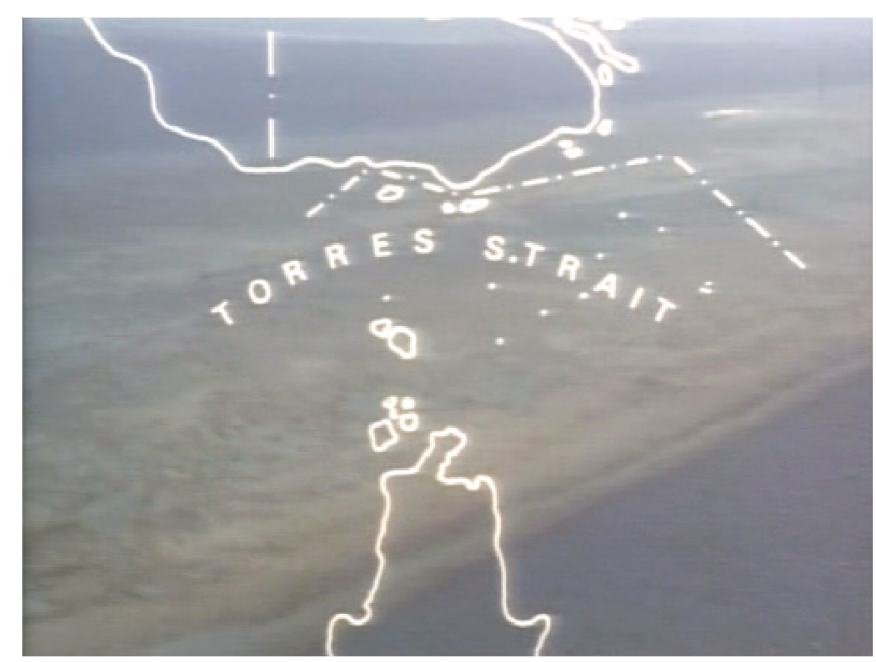

Figure 2: Screenshot from Talking Broken - Torres Strait Map (C) 1990 Frances Calvert

Calvert is clearly playing on that tradition. She literalizes the cartographic component within such a panoptic view by combining a zoom shot of a semitransparent Torres Strait map and a dissolve as it transitions spatially from Cape York on the Australian mainland to the Torres Strait Islands (figure 2). So far, these are conventional establishing shots spatially locating the islands, and the use of the map explicitly evokes forms of colonial representation that have seeped into postcolonial popular culture. One might think here of the Indiana Jones films, for instance. In a similar vein, Calvert also uses inter-titles in a direct reference to her silent film precursors, such as Frank Hurley (figure 6).

However, such conventions are deliberately and ironically breached by the presence of the "talking broken" helicopter/telephone-booth motif. Instead of functioning to highlight the islands' sense of isolation, the establishing shots here function both to highlight such shots' own artificiality or artefactuality, and to segue in most cases into highly mediatized spaces. For example, the first section of the film opens into an implicit commentary on radio, and the media section, which I will discuss in a moment, opens out into a commentary on television, video games and film under the category of "light entertainment".

The sense of artificiality or artefactuality of the motif is heightened by the fact that it occurs sporadically throughout the film, breaking with the 
temporal convention of arrival, ${ }^{7}$ and it occurs in jarring or discontinuous sequences, breaking with the spatial convention of establishing that arrival in a particular location. ${ }^{8}$ To that extent, it functions more as a visual punctuating marker and a commentary on the relationship between space, place and media. Indeed, apart from its striking visual appeal, one of the reasons why I think Calvert focuses on the telephonebooth as a motif is that such a relationship becomes an analogue of the spatial ambiguities of the islands. Just as the Torres Strait Islands are separated and joined together by the sea, the telephone-booth separates out private linguistic spaces (or intimacies) that are joined together within an interconnected or networked public space. The telephone-booth therefore becomes the ideal space within which to have Calvert's protagonists announce the coming topic at hand, and laying this image over shots of the islands serves to make the spatial connection.

Unlike prior such establishing shots in earlier films, such as Frank Hurley's, for example, where you may glimpse a faint shadow or mirrored reflection of a filming aircraft or its triumphant departure or return, the filmed helicopter in this context becomes a direct mirror image of the invisible filming helicopter, highlighting the immediate presence of both. There is a sense of symmetrical reciprocity between them: the one focused on the relationship between flight and vision, the other on the relationship between distance and sound. In both cases, there is an implied commentary on the technological mediation of the senses.

This leads on to the other great cliché of Torres Strait film: the use of, often decontextualized and exoticized, anthropological field recordings of Indigenous Torres Strait music played over the aerial opening sequence. Calvert breaks with this convention, and thus with the illusion of representing the Torres Strait as if from an unmediated "Islanders" point of view, by always accompanying the "talking broken" telephone motif with a dense soundtrack of ambient sounds (the sea, wind, etc.), recordings of Torres Strait Islanders literally talking Broken/Yumplatok on the telephone and Karlheinz Stockhausen's 1968 composition, Stimmung. ${ }^{9}$ "Stimmung" has many associated meanings in German, but they centre on the idea of a mood, atmosphere or tuning, with the root implication of a voice (in this case, a series of non-linguistic voices, often using overtones, that are "tuned" like an instrument, or indeed a radio).

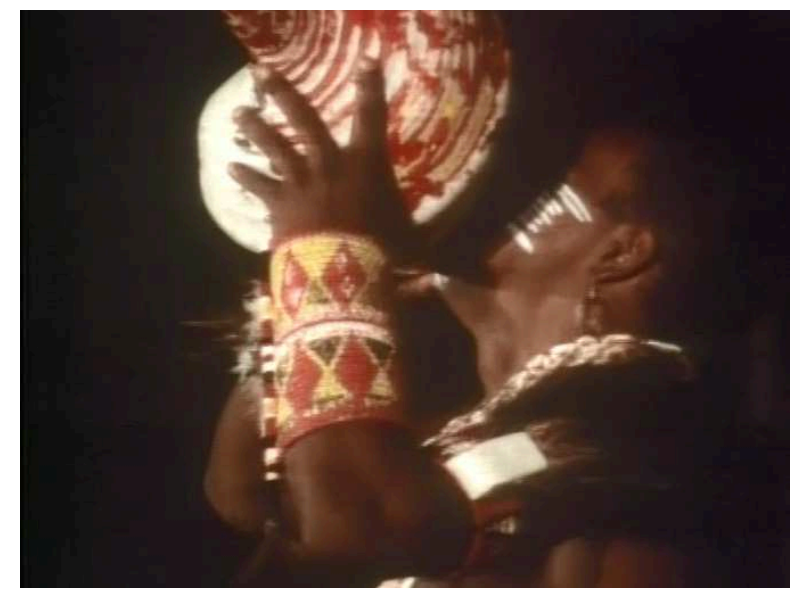

Figure 3: Screenshot from Talking Broken - Shell horn (c) 1990 Frances Calvert

In my reading, Stockhausen's Stimmung becomes a meditation on the uncanny voice, the voice that, through the use of such overtones, becomes difficult to individuate or to distinguish from mediation or instrumentation: how many voices are there? Where does one begin and end? Are these amplified, modified or processed voices? Indeed, are they voices at all or are they instruments? ${ }^{10}$ I think that these questions are playing through Calvert's use of both the recorded telephonic voices and the "talking broken" telephone-booth motif more generally: less a binary of broken versus fixed, then, and more a meditation on the complexities of linguistic and cultural hybridity or mediation.

Calvert's use of this leitmotif is part and parcel of a broader figure of irony, or ironic reversals, in her early work (Calvert and Purser 311). For example, in her subsequent film, Cracks in the Mask (1997), Calvert takes an ironically inverted ethnographic gaze and directs it back at European museums and their Indigenous holdings (Calvert and Purser 307-308). ${ }^{11}$ As I mentioned earlier (footnote 10), the use of music in the film was also deliberately and self-consciously ironic. Indeed, to some extent, Calvert's early films, and Talking Broken in particular, can be seen as an ironic 
commentary on, and absorption of, prior Torres Strait film per se. This includes the playful use of prior, and particularly silent film, conventions (such as the aerial shot and intertitles, etc.), and the direct appropriation and re-signification of carefully edited archive film. Two illustrative examples of the latter appear in Talking Broken. In the first, Calvert cuts from an interview about contemporary Indigenous absorption within a capitalist world system to an archive clip of the pearling industry taken from a 1937 government propaganda film, The Native Problem in Queensland. This juxtaposition has an added resonance in that The Native Problem was, in part at least, made in response to a mass strike on the islands in 1936 (The National Film and Sound Archive). In the second, Calvert cuts from a somewhat martial contemporary school assembly on Boigu Island, where the students sing the Australian national anthem, "Advance Australia Fair", to a shot of flag-wielding colonial discipline and paternalism in the same film. In both cases, she leaves the soundtrack of the first shot running over the selected images of the second in order to make the point. The ironic collapse of (post-)colonial past and present is striking, playful and effective at re-signifying the images. However, in both cases, the juxtapositional shift from one set of shots to the next implies historical continuity without the need to provide a detailed historical narrative. This is more of a fragmentary invocation or evocation of experiential "pastness" than it is an historical narrative (Baron). To that extent, the film owes a certain debt to the cultural discourses of postmodernism (irony, pastiche, fragmentation and bricolage, etc., Calvert and Purser 311), but it is not, I think, reducible to that context. Such a disjuncture between past and present, "pastness" and history is structurally embedded in the use of archive media in film more generally (Baron).

\section{Space, Place and Media}

However one might choose to characterize this process of archival appropriation, the broader figure of irony undoubtedly plays an important role in Calvert's early work, and it is particularly heightened in the crucial "media" section of the film, which begins with a series of visual and verbal puns: firstly, a shot of a photograph being taken of an Anglican bishop (Kiwami Dai from Saibai Island) alongside a group newly confirmed by him on Thursday Island (figure 4).

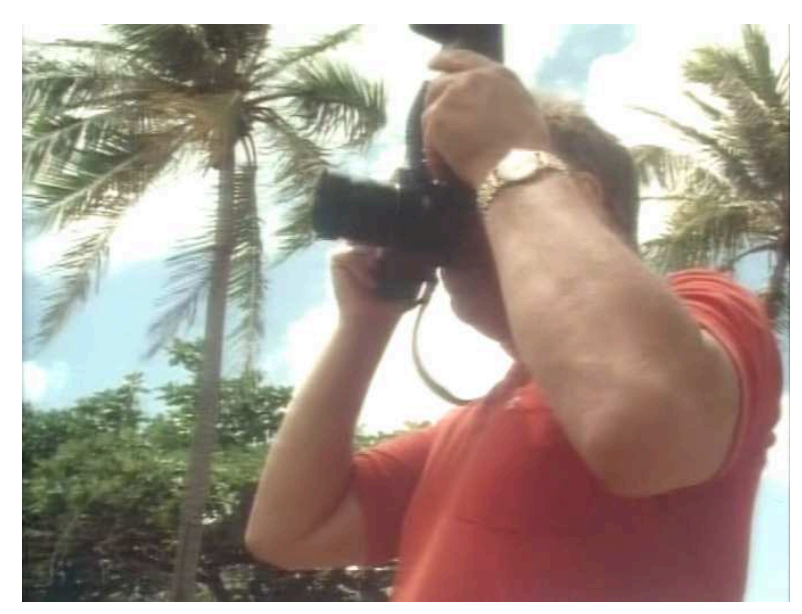

Figure 4: Screenshot from Talking Broken - Photography (๑) 1990 Frances Calvert

This is a visual pun on the island term for the arrival of Christianity in 1871 via the London Missionary Society, the so-called "coming of the light". This cuts to the "talking broken" telephone motif, where the conversation centres on the latest Batman movie, Tim Burton's 1989 film (figure 5), and then an inter-title announcing the most media-focused section of the film: the "coming of light entertainment" (figure 6). This is both a pun on the shift from religion to mediatized entertainment and a play on the duality of light versus heavy and light versus dark. In a self-reflexive or recursive mode, Calvert then lingers on a reflection in a television screen of the Islanders filming and watching themselves on a television screen (figure 7). This cuts to an extended discussion of language, land rights, cultural identity and media with the famous-and now sadly deceased-Torres Strait cultural historian and custodian, Ephraim Bani (1944-2004) (figure 8). In a repeat of the juxtapositional shifts I mentioned earlier, the soundtrack of Ephraim's critical commentary is juxtaposed, firstly, against archive photographs produced under direct colonial rule (figure 9), and then contemporary filmed images of children playing video games in an arcade (figure 10) and VHS rental copies of globally popular film titles, such as Mad Max and Rocky. 


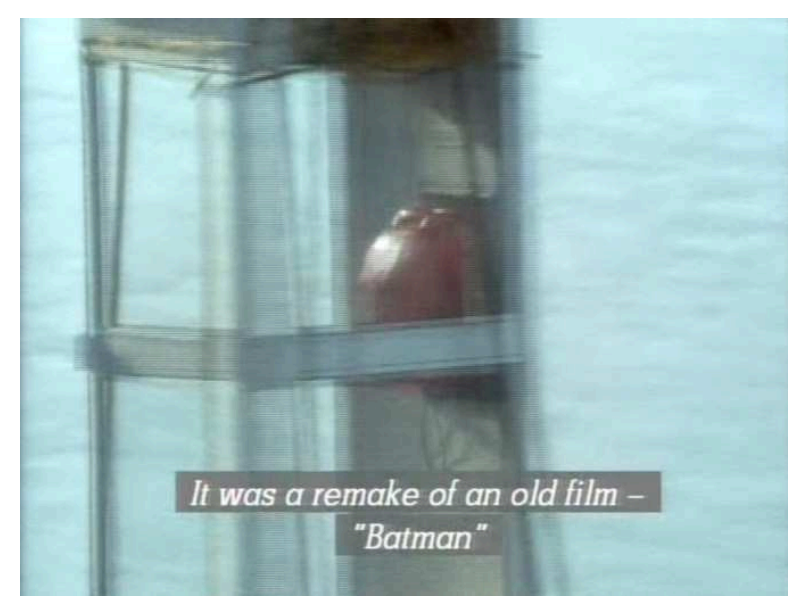

Figure 5: Screenshot from Talking Broken - The "talking broken" motif, 2 (C) 1990 Frances Calvert

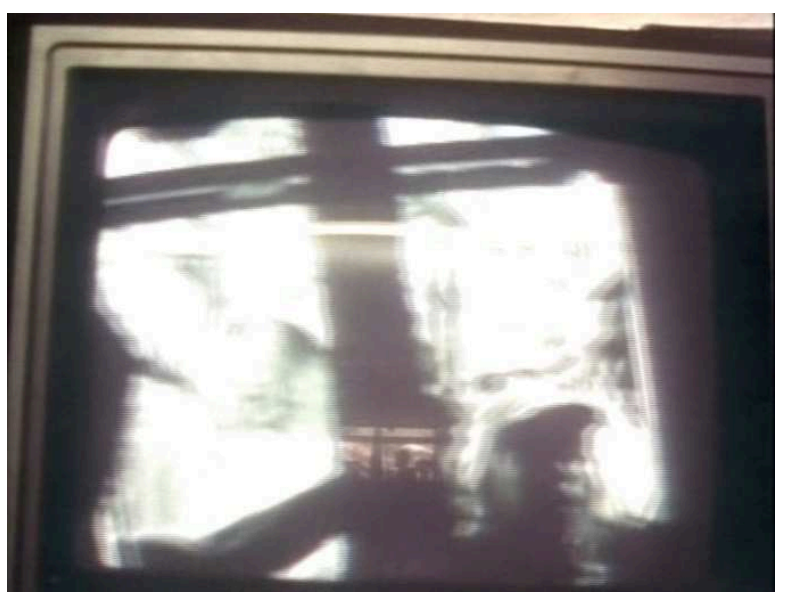

Figure 7: Screenshot from Talking Broken - Television (C) 1990 Frances Calvert

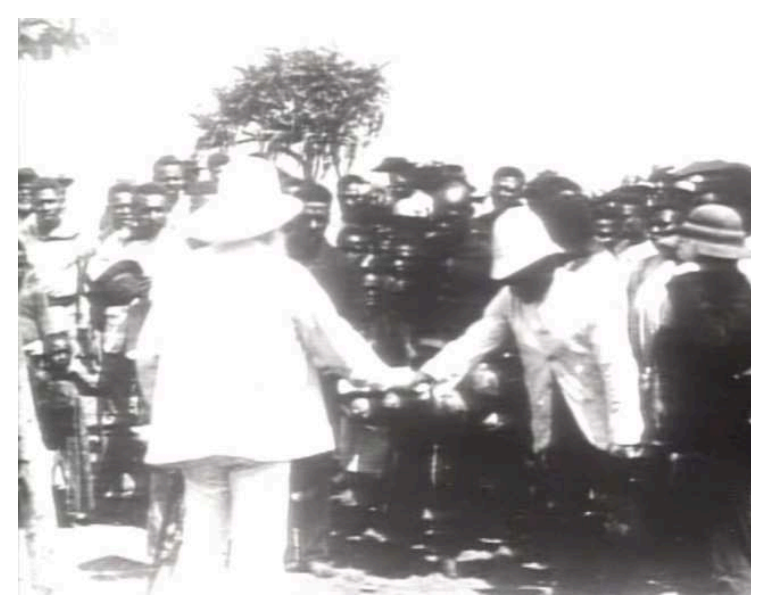

Figure 9: Screenshot from Talking Broken - Archival photograph (C) 1990 Frances Calvert

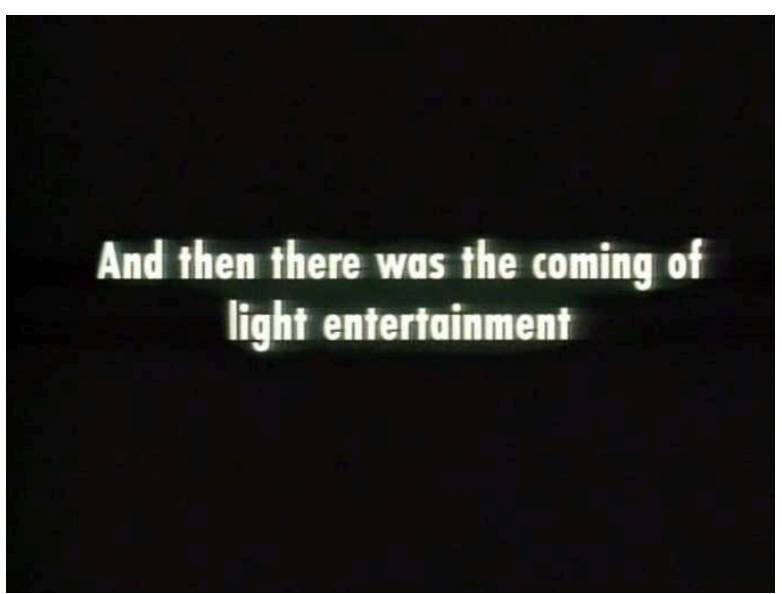

Figure 6: Screenshot from Talking Broken - "[T]he coming of light entertainment” (c) 1990 Frances Calvert

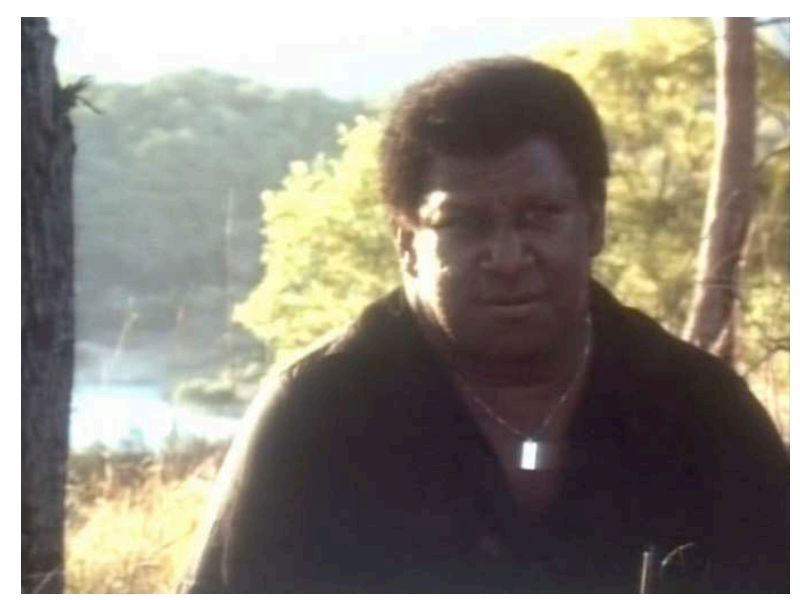

Figure 8: Screenshot from Talking Broken - Ephraim Bani (C) 1990 Frances Calvert

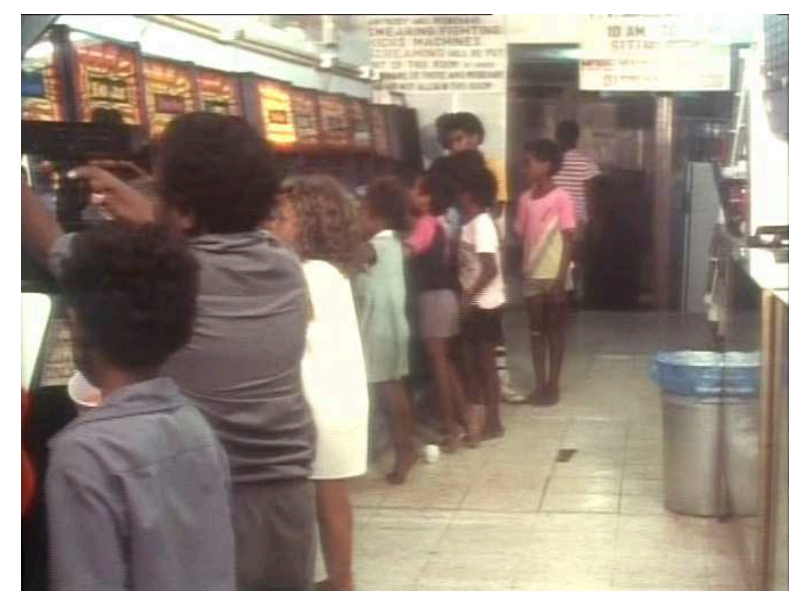

Figure 10: Screenshot from Talking Broken - Video arcade (C) 1990 Frances Calvert 


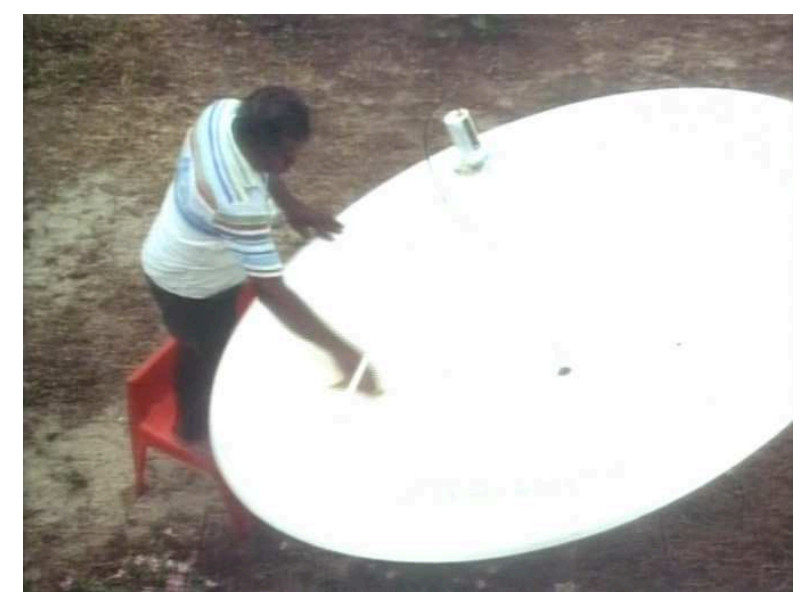

Figure 11: Screenshot from Talking Broken - Satellite dish (c) 1990 Frances Calvert

Such juxtaposed sequences are undoubtedly intended to be ironic and jarring, and they do make significant inroads into re-signifying the images, particularly the archival photographs, but the point here is not, I think, to make a simplistic claim to "pristine" Indigenous local identities being destroyed by globalized media, but rather to focus on the complexity of contemporary local/global hybridization and the extent to which such hybridity has a long past that precedes colonization, has outlived it and will continue in and through contemporary media rather than outside of them. Indeed, as the main protagonist in the debate, Bani goes on to discuss the importance of not dismissing such media forms per se, but of controlling them, and this is a crucial tenet of contemporary Indigenous media theory (e.g. Hokowhitu and Devadas): not only is control over representations important-but control over the means and institutions of representations (e.g. TV channels, media outlets, etc.).

As Calvert lingers on a Torres Strait Islander polishing a satellite dish (figure 11), Bani suggests that:

[...] the counter-attack for this outer influence-outer impact-is inventing our own programmes, promoting our culture through media. $^{12}$

This sentiment tallies with Calvert's description of the film as "post-colonial", by which she means an exploration of how Indigenous groups "are reacting [to the lingering after-effects of colonialism], how they have been influenced, how they are trying to take power into their own hands" (McInerney 24). Such a reclamation of power refers as much to the cultural politics of media as to wider political and economic issues. Indeed, for the cultural politics of media to be effective in warding off the type of disempowering state paternalism that anthropologist Jeremy Beckett (ch. 7) refers to as "welfare colonialism", there is a necessary correlation between culture, politics and economics, a point that Bani understood all too well. In reference to the film, Marie McInerney makes a similar point by suggesting that such welfare colonialism is seductive, but ultimately disenfranchising, in offering the allure of money but without the positive correlate of power:

Now they are learning that some government schemes have to fail, that policies change with governments, and that paternalism can be comfortable but has its price. (McInerney, 24)

Effective methods of taking back control must operate across the realms of culture, politics and economics, albeit with different strategic points of emphasis at different times.

\section{Conclusion}

In effect, Bani and Calvert were both predicting the emergence of possible future initiatives, such as the National Indigenous Television Network, which began broadcasting in 2007, three years after Bani's death. In an ironic circularity, this film, and Calvert's later film, Cracks in the Mask (1997), which also centres on Ephraim, are regularly shown on the network, as well as on a loop in the Gab Titui Indigenous Cultural Centre on Thursday Island. It is at this point that the "Broken" of the title comes to stand more for the cautious and never innocent hopes of hybridity than for the nostalgic anxieties surrounding a cultural purity that never was. Such hopes are, in part, being realized by the increased role that Torres Strait Islanders are taking not only in generating more representative media, through consultation/participation, etc., but in controlling more 
of the ownership and/or production of such media themselves and their institutions. Examples include the Torres Strait Media Association, the Torres Strait Regional Authority (Charles), Torres Strait Online Television, the films of Llew Cleaver, Aaron Fa'aoso, Murray Lui, Aven Noah, Rhianna Patrick and Douglas Watkin (see the film and television section), or the music and videos of highly successful performers like Christine Anu and Mau Power, to choose but a small representative sample. Whilst there is much work to be done, and critical vigilance is always required, these developments have seemingly been made possible through a combination of political agitation, media training and the reduced costs and wider availability of recording and communications media, etc.

I would suggest that there is a broader lesson here for an engagement between postcolonial studies and media theory that stresses the interplay of semiotic and contextual registers, not least because the significance of such an approach is not just methodological; there are core political and ethical issues to consider in relation to Indigenous identities, reception histories and media production. It is clearly the case that appropriating such media for the purposes of Indigenous cultural continuity or revival, or for Indigenous attempts to wrest back control of media production, poses cultural, political and economic risks: not least the risk of being $r e$-appropriated in turn by a global neoliberalism that absorbs, or even actively solicits, Indigenous representations, but in so doing marketizes and/or neutralizes any critical commentary. In other words, such absorption runs the risk of naturalizing the market in order to neutralize critique. Any attempt at media reclamation in that context is therefore encrusted with prior histories and problematic and fractious presents, but, in an era of global media saturation, therein lie some of the most important strategic and creative choices for the future.

\section{Acknowledgements}

Special thanks are due to Frances Calvert for extremely useful comments on an earlier draft of this article and for her generosity of time and spirit. All are greatly appreciated.

\section{Notes}

1. Fernández appears to have in mind mainly new media theory from the early to late-1990s that addressed, and sometimes celebrated, the growth of digital media but often without detailed reference to global power differentials (Fernández 59). Conversely, the postcolonial studies (plural) that emerged in the aftermath of some of its core early protagonists (e.g. Homi Bhabha, Edward Said and Gayatri Chakravorty Spivak) often used the theories and methods of comparative literature to address such power differentials but without sustained engagements with the role that other media might play. The point is that these are broad-brush observations rather than uncritical absolutes.

2. Merten and Krämer; Weaver-Hightower and Hulme; Schwarz and Eckstein; and Sandra Ponzanesi and Waller.

3. The documentary was shot on $16 \mathrm{~mm}$ film and released also on VHS and DVD. It has been distributed in Australia, America and Europe and has been screened at more than a dozen festivals, including in the Torres Strait (McInerney 24), and on television in the UK, Australia and Germany (Calvert n.d.).

4. The choice of funding bodies indicates both something of the practical vagaries of film funding (Calvert was based in Germany and found funding easier to come by there and in the UK than in Australia, despite the project having the "stamp of an Australian film") as well as something of the international focus of the film (McInerney 24). Calvert directed the film, partly at least, in response to the German audiences' perceived reaction against didactic documentaries and towards a more discursive or polemical style (McInerney 24).

5. In the Papuan portion of Frank Hurley's 1921 film, Pearls and Savages, Hurley suggests that " $\mathrm{t}]$ he natives regard the flying men as gods come from the skies" and proceeds with a shot of Papuans in boats seemingly reverently circling the sea plane.

6. A similar re-signification of the aerial shot occurs later in the film when Calvert juxtaposes a sweeping aerial view of the islands with the soundtrack of a speech about colonialism, self-governance and land rights by the prominent island figure, Chairman Mau.

7. In her 1997 "sequel" to Talking Broken, Cracks in the Mask, Calvert similarly plays ironically on the arrival scene by having the film's main Torres Strait protagonist, Ephraim Bani, arrive in Neuchâtel, Switzerland as if by boat. This, she suggests, is to avoid the "flat realism" of conventional arrival scenes (Calvert and Purser 311). It also plays ironically on the classic ethnographic arrival as well as the significance of boats and the sea to Torres Strait Islanders (Calvert and Purser 311). 
8. Calvert suggests that, unlike the linearity of her second film, Cracks in the Mask (1997), Talking Broken is structured more like a "mosaic" (Calvert 1999, 12).

9. In an interview in 1997, Calvert talks about similar musical choices in Cracks in the Mask (1997). She suggests that she wanted the music "to work in an ironic way" (Calvert 1999, 16). I will come back to the important question of irony in her work a little later.

10. For example, at one point Calvert combines the soundtrack of such voices with a shot of a shell horn being blown (figure 3 ).

11. It is worth stressing that the impetus behind such an inversion came from Ephraim Bani himself at the end of Talking Broken (Calvert and Purser 307-308). This made Cracks in the Mask something of a sequel (Calvert and Purser 308).

12. In a characteristically wry commentary on this statement, Calvert follows Bani's discussion with a short "home video" section filmed by the "boys of Moa Island one night in our absence". Although filmed in a jocular tone, implied themes from this short section include family, global environmental issues, religion and music.

\section{References}

Ashcroft, Bill, Gareth Griffiths, and Helen Tiffin. The PostColonial Studies Reader (2nd ed.). London/New York: Routledge, 2005. Print.

Baron, Jaimie. The Archive Effect: Found Footage and the Audiovisual Experience of History. London/New York: Routledge, 2014. Print.

Beckett, Jeremy. Torres Strait Islanders: Custom and Colonialism. Cambridge: Cambridge University Press, 1987. Print.

Bennett, Tony, Pat Buckridge, David Carter, and Colin Mercer. Celebrating the Nation: A Critical Study of Australia's Bicentenary. St. Leonards: Allen \& Unwin, 1992. Print.

Bolter, Jay D., and Richard Grusin. Remediation: Understanding New Media. Cambridge, MA: MIT Press, 1999.

Calvert, Frances. "Peter Malone interviews Frances Calvert.” Nelen Yubu, 71 (1999): 9-17. Print.

Calvert, Frances, and Emily Purser. "Moving Images, Making Meanings.” Derrière les images. Neuchâtel: Musée d’ethnographie, 1998. 307-336. Print.

Dixon, Robert. Prosthetic Gods: Travel, Representation and Colonial Governance. Brisbane: University of Queensland Press, 2001. Print.
Fernández, María. "Postcolonial Media Theory." Art Journal, 58.3 (1999): 58-73. Print.

Herle, Anita, and Sandra Rouse. Cambridge and the Torres Strait: Centenary Essays on the 1898 Anthropological Expedition. Cambridge: Cambridge University Press, 1998. Print.

Hokowhitu, Brendan, and Vijay Devadas. The Fourth Eye: Māori Media Aotearoa New Zealand. Minneapolis/ London: University of Minnesota Press, 2013. Print.

McInerney, Marie. “Germans Fund Australian's Torres Strait Islanders Film." The Canberra Times, 6 May 1991: 24. Print.

Merten, Kai and Lucia Krämer, eds. Postcolonial Studies Meets Media Studies: A Critical Encounter. New York: Columbia University Press, forthcoming 2016. Print.

Ponzanesi, Sandra, and Marguerite Waller, eds. Postcolonial Cinema Studies. London/New York: Routledge, 2011. Print.

Pratt, Mary L. "Fieldwork in Common Places." Writing Culture: The Poetics and Politics of Ethnography. Eds. James Clifford, and George Marcus. Berkeley/Los Angeles/London: University of California Press, 1986. 27-50. Print.

Sharp, Nonie. Stars of Tagai: The Torres Strait Islanders. Canberra: Aboriginal Studies Press, 1993. Print.

. No Ordinary Judgement: Mabo, The Murray Islanders' Land Case. Canberra: Aboriginal Studies Press, 1996. Print.

Schwarz, Anja, and Lars Eckstein. Postcolonial Piracy. London: Bloomsbury Academic, 2014. Print.

Thornham, Sue, Caroline Bassett, and Paul Marris. Media Studies: A Reader (3rd ed.). Edinburgh: Edinburgh University Press, 2009. Print.

Turner, Graeme. Making it National: Nationalism and Australian Popular Culture. St. Leonards: Allen \& Unwin, 1994. Print.

Virilio, Paul. War and Cinema: The Logistics of Perception. London: Verso, 2009. Print.

Weaver-Hightower, Rebecca, and Peter Hulme. Postcolonial Film: History, Empire, Resistance. London/ New York: Routledge, 2014. Print.

Wilson, Pamela, and Michelle Stewart, eds. Global Indigenous Media: Cultures, Poetics and Politics. London: Duke University Press, 2008. Print.

\section{Film and Television}

Bagnall, Frank, dir. Pearlers of the Coral Sea. Australian Commonwealth Film Unit, 1960. Film. 
Bleakley, John W., dir. The Native Problem in Queensland. Department of Health and Home Affairs, 1937. Film.

Charles, Brett, dir. Ailan Kastom. Leftfield Productions, 2013. Film.

Calvert, Frances, dir. Talking Broken. Talking Pictures, 1990. Film.

Cracks in the Mask. Talking Pictures, 1997. Film.

Cleaver, Llew, dir. Douglas Pitt. SBS Television, 2001. Television.

. Native Title: Return to Ugar. SBS Television, 2001. Television.

Torres Strait Islander Autonomy: Masig. SBS Television, 2001. Television.

Fảaoso, Aaron, dir. Bit of Black Business - Sharpeye. Scarlett Pictures, 2007. Film.

Graham, Trevor, dir. Land Bilong Islanders. Yarra Bank Films, 1990. Film.

Mabo: Life of an Island Man. Film Australia/ Tantamount Productions, 1997. Film.

Haddon, Alfred C., dir. Torres Strait Islanders. Cambridge University, 1898. Archive Film.

Hall, Ken, dir. Lovers and Luggers. Cinesound Productions, 1937. Film.

Holmes, Cecil, dir. The Islanders. Australian Commonwealth Film Unit. 1968. Film.

Hurley, Frank, dir. Pearls and Savages. Stoll Hurley Productions, 1921. Film.

The Hound of the Deep. Stoll Hurley Productions, 1926. Film.

Hylands, Andrea, and Peter Hylands, dirs. Ken Thaiday Snr: The Sea, the Feather and the Dance Machine. Creative Cowboy Films, 2011. Film.

Alick Tipoti: Zugub, the Mask, the Spirits and the Stars. Creative Cowboy Films, 2012. Film.

Lui, Murray, dir. Tombstone Unveiling. Central Australian Aboriginal Media Association, 2000. Film.

Noah, Aven, dir. Small Island, Big Fight. Film Australia, 2000. Film.

Patrick, Rhianna, dir. A Close Shave. ABC TV, 2002. Television.

. Coming of the Light. ABC TV, 2006. Television.

Robinson, Lee, dir. King of the Coral Sea. Southern International, 1954. Film.

Watkin, Douglas, dir. Malaytown Stories. Douglas George Watkin, 2006. Film.
. Troubled Waters. ABC TV, 2007. Television.

. Frangipani Land Forever. ABC TV, 2008.

Television.

. Green Warrior. ABC TV, 2008. Television.

Lagau Danalaig. Lacework Productions, 2012.

Film.

\section{Websites}

Australian Screen, Pearls and Savages, n.d. Web. 22 Feb. 2016. <http://aso.gov.au/titles/documentaries/pearlsand-savages $/>$.

Banks, Joseph, "The Endeavour Journals, 1770 July 20", Nov. 2005. Web. 22 Feb. 2016. <http://gutenberg.net. au/ebooks05/0501141h.html\#jul1770>.

Calvert, Frances, “Talking Broken,” n.d. Web. 22 Feb. 2016. $<$ http://www.calvert-film.com/talking.html $>$.

Cook, James, "The Endeavour Journals," 2004. Web. 22 Feb. 2016. <http://southseas.nla.gov.au/journals/cook/ contents.html>.

The National Film and Sound Archive, The Native Problem in Queensland, n.d. Web. 22 Feb. 2016. $<$ http://www.nfsa.gov.au/digitallearning/mabo/info/ nativeProblemInQld.htm>.

The State Library of Queensland, "Languages of the Torres Strait Islands," 2016. Web. 22 Dec. 2016. <http://www. slq.qld.gov.au/resources/atsi/languages/torres-strait>.

Recebido em: 29/02/2016 Aceito em: 02/05/2016 